\title{
Ideological Origins of Symbolic Culture of Japanese Diet
}

\author{
Xuejing He \\ English Department, Sichuan Minzu College, Kangding, Sichuan, 626001 \\ daphne315@163.com
}

Keywords: Symbolic Culture of Japanese Diet, Ideological Origin, Belief in Animism, Belief in Ujigami

\begin{abstract}
To interpret the symbolic culture of Japanese diet, this paper uses the theories and approaches of Symbolic Anthropology, takes the dietary activities in Japanese annual events as examples, illustratesthe symbolic meanings of food and analyses the ideological origins, which are belief in animism and belief in Ujigami.
\end{abstract}

\section{Introduction}

In Symbolic Anthropology, culture is an explanatory text and is full of symbolic forms and symbolic meanings. Geertz described culture as a system of inherited conceptions expressed in symbolic forms[1]. In order to precisely interpret the symbols of each culture, the task is to arrange the symbolic forms thoroughly, explain the various symbolic meanings completely and analyses the concealed ideological origins. Thus the cultural essence could be lifted up in a brand new level.

The food culture is a common phenomenon on eating and drinking. Symbolic culture of diet belongs under the food culture. In symbolic culture of Japanese diet, food and beverage are taken as the main dietary symbolic forms and are used as the ways of sending messages. Dietary activities, as the guiding symbolic forms of Japanese food culture, convey symbolic meanings. Compared to the common function of eating and drinking, symbolic culture of Japanese diet focuses much more on nature and security, social lives, misfortune and fortune, health and longevity, religionand believes, and so on. The symbolic meanings can be explained and experienced through dietary activities.

This paper takes Japanese annual events as example, which refers to the traditional festivals in ancient and modern Japan, regards symbolic culture of Japanese diet as an explanatory text, explains the symbolic meanings and analyzes the ideological origins of dietary activities, points out the original believes are the promotion for Japanese dietary life and Japanese food culture, and the basic power of progress in Japanese culture and Japanese civilization.

\section{The Fundamental Believes of Symbolic Culture of Japanese Diet}

In Japanese annual events, the dietary activities have been regarded as the symbolic forms for thousands of years, which are the symbolic expressions of Japanese common mind, mentality, thought and emotion. Belief in animism and belief in Ujigami are the fundamental believes of Japanese and the ideological origins in symbolic culture of Japanese diet.

\section{Belief in Animism}

Animism is a belief that all natural phenomena and objects have spirits. In primitive society, the island country is the supply of food and residence for Japanese, and is often accompanied by volcano, tidal wave, earthquake, etc. The ancient Japanese feels helpless, fearful, awful, and mysterious, and get puzzled by natural disasters. Gradually, natural phenomenon, such as mountains and rivers, the sun, the moon and the stars, is considered to be spirits. The spirits are believed to be everywhere and in everything by ancient Japanese, and are enshrined and 
worshipped to pray for no strike of disasters and for safe and well. In Japanese dietary activities, animism can be explained in symbiosis and sharing meals with spirits.

Symbiosis is a collaborative relationship between different species, which is also called the ecological symbiosis [2]. The nature provides appropriate living environment for the Japanese. At the same time, the Japanese follows the natural law and actively complying with nature. In Gosekku(the five seasonal festivals), the Japanese follows the rhythm of nature and seasonal dishes. The word "Sekku" both refers to the foods enjoyed in the festival and the seasonal festival itself. On January 7, Jinjitsu (the People's Festival) is celebrated and is also called Nanakusa-no-sekku (the feast of seven herbs). Nanakusa-gayu (seven-herb rice porridge) is precious at the beginning of the year, as the green vegetables are rare. The nanakusa are seven wild herbs, which have the function of ensuring good health for the coming year. Shirozake (white wine made from fermented rice) and hishimochi (diamond-shaped rice cake in red, green and white color) are prepared in Jyousi-no-sekku (the Girl's Festival). The color of the food implies good wishes for the girls. Red has the power of protecting against evil, green symbolizes health and vividness, and white is an emblem of purity and cleanliness. Kashiwa-mochi (rice cakes wrapped in oak leaves) and Chimaki (sweet rice paste wrapped in iris leaves) are popular in Tango-no-sekku (the Iris Festival). Oak leaves and iris leaves are believed to be medicinal herbs and can get rid of disease. Saku-bei (fried string-shaped rice cake) is laid out in Tanabata-no-sekku (the Star Festival). Saku-bei, the origin of noodle, represents the cloth offered to the deity to pray for protection of good harvest. Kiku-sake (chrysanthemum wine) is shared in Kiku-no-sekku (the Chrysanthemum Festival). Chrysanthemum is considered to have cleansing and curing function. All the foods in Gosekku are deemed to be the symbols of warding off evil, the symbols of longevity and health, and the symbols of coexisting with nature. Living with the natural rhythm and seasonal food, the Japanese experiences the cycle of the changing nature and lives in harmony with nature.

Sharing meals is believed to be derived from the symbiotic relationship. Believing the foods are the gifts and favors from nature, the ancient Japanese take the plants and animals as spirits, and also offer sacrifices to show their gratitude. The sacrifices in Japanese annual events are foods and beverage to express thanks and respect. In New Year's Day, the essential and precious foodstuffs are offered in family alter, such as rice, salt, water, rice cake, orange, vegetables, fruits, etc. In Daijyo-sai Festival (first ceremony held by newly-enthroned Emperor to offer rice), the Emperor offers foods and beverage to the deities. The staple foods are the newly-harvested rice, rice and porridge boiled by millet, the white sake and black sake made by newly-harvested rice. The side dishes are 4 types of fresh fish, dried fish and fruits, vegetables, soup, and so on[3]. The offerings are the symbolic forms of sharing meals, the symbolic forms of ancient Japanese food category and dietary habits and the symbolic forms of reciprocal relationship between people and deities. It is believed that the offering possesses mystery power. People who eat them will get the supernatural power. With the divine protection, the Japanese are able to create abundant food and superior living condition for families and deities. The deities who share the offerings become stronger, and they get strengthened of protecting the safety and the health of people, protecting people against natural disasters and providing people with much more comfortable surroundings. The offerings are means of communicating between Japanese and deities and are symbolic expressions in relationship between people, nature and deities. The Japanese and the nature depend close on each other and live together in collaboration.

\section{Belief in Ujigami}

Ujigami (the guardian deity of a village) is the mass of souls of ancestor without specific personality [4]. The Japanese pray to Ujigami for protecting from disasters and sickness, succeeding in endeavors, etc. The term Ujigami refers to a family deity, which can be explained in three aspects. First, Ujigami means ancestor. Ancestor is not a single person, but a group of people who found the family and succeed to the family business. Second, Ujigami doesn't have specific personality. For 30 years, Japanese have been holding service in memory of the souls of the departed ancestor. The souls get purified and the personalities get removed for the long 
period of worship. Third, Ujigami is the mass of souls. The newly purified souls are welcomed to join in the existed souls of ancestor. Ancestor becomes greater and greater by propagation, and Ujigami becomes a developing mass of souls. Over time, Ujigami is regarded asancestor. Belief in Ujigami is the admiration, devotion and love for ancestor. Belief in Ujigami is viewed as ancestor worship.

The act of ancestor worship can be founded in the dietary activities in ordinary family. In Bon Festival (Festival of the Dead), prayers are offered by Japanese to worship their ancestor. To welcome the souls, a horse-shaped cucumber and a bull-shaped eggplant are displayed on the altar. It is believed that the ancestor ride the horse home and the luggage are carried on bull's back. Mizunomi (mixtures of fine cut cucumber, eggplant, cowpea, washed rice, and so on) [5] is also offered for the ancestor after a long tired journey. The foods in the worship play the role of communicating between ancestor and descendent, and express the remembrance of ancestor. The foods are the symbolic forms of mutual community of Japanese family. The Japanese works with care and energy for family growing and makes every effort to live in happy life. It is believed that the hard-working people will be worshipped by their descendent and will join in ancestor. After the deceased becomes Ujigami, he is capable of protecting the wealthy of the family and the safe and sound of the descendent. For the living people,to become ancestor is the internal motivation to work diligently and worship the ancestor constantly. The propagation of family member and the inheritance of family business are realized by the result of one's struggle and the protection of ancestor. It's the mutual effort by people and Ujigami. The service of ancestor worship are the symbols of reciprocal affection and help between ancestor and descendent and the expression of family ties.

Belief in Ujigami can be also founded in two significant ceremonies held by the Emperor. In the mythological age of Japan, the Amaterasu-ookami possesses the royal prerogative of heaven, the Emperor, the descendent of the Amaterasu-ookami, exercises the supreme power in this world. The Emperor, the Ujigami of the royal family, has the highest position and the greatest power in Japanese imperial family. In Niiname-sai Festival (the ceremony held by the Emperor to offer the deities with newly-harvested rice), the Emperor offers the newly-harvested rice and other foods and beverage to the Amaterasu-ookami (the God of Sun) and other deities. The Emperor sits face-to-face with theShinza (place where there is deity). In order to worship the deities, the Emperor uses bamboo chopsticks to get the foods from the leaf bowls, and then puts them into the leaf plate [6]. Later the Emperor shares foods and beverage with deities. When the new Emperor accedes to the throne, a ceremony is held to express thanks to deities. In Daijyou-sai Festival, the boiled newly-harvested rice and porridge, and the white wine and black wine made of newly-harvested rice are offered, one by one, to the deities by the Emperor. At a later time, the Emperor and the deities enjoy the meals, have the newly boiled rice and drink the newly brewed wine [7]. In Niiname-saiFestival and Daijyou-sai Festival, the Emperor plays two roles in the ceremony; the one holds the ceremony as a priest and the other one to be the idol of worship. The Emperor offers foods to the Amaterasu-ookami, to pray for the safety, good harvest, health and wealth, prosperity of the country and the happiness of the people. The power of the deities is transferred to the Emperor while enjoying the meal. Meantime, the Emperor becomes the deities' representative at the ceremony. The Emperor gets the quality of being a deity and is considered to be Arahitogami (living deity). That is to say, the deity appears in the real world in human form. The act of sharing meals is the symbol of human-deity unity. The act of Emperor-worship is the symbol of cohesion of the country and the unity of the people.

\section{Conclusion}

In Japanese annual events, the dietary activities, the symbolic forms of symbolic culture of Japanese food, conceal the profound ideological origins. Belief in animism and belief in Ujigami are the knowledge on nature, human and society, the philosophical thinking on eternal life and universal verities, and the open-minded ideology. Under the influence of the ideological origins, the Japanese receives and absorbs the foreign culture willingly, and get self-refreshed gradually. 
It is a new method to interpret the Japanese food culture in the view of Symbolic Anthropology. It is useful for us to better understand the fundamental believes of Japanese generally and to learn the mental basis of Japanese deeply. It not only enlightens us to consider the ideological origins in Chinese food culture, but also awakens the self-consciousness of culture.

\section{Acknowledgements}

This paper is supported by the project of Sichuan Minzu College. The project name is: Research on the Symbolic Culture of Japanese Diet Based on Japanese Annual Events (No.XYZB16006).

\section{References}

[1] Information on https://en.wikipedia.org/wiki/The_Interpretation_of_Cultures

[2] Zhaorong Peng. Anthropology of Food [M]. Beijing: Beijing University Press, 2013: 267. (In Chinese)

[3,6,7] Jinlin Wang. The Original Believes of Japanese [M]. Yinchuan: Ningxia People Press, 2004: 63-65. (In Chinese)

[4] Hisashi Nagata. Learn Annual Events of Japan Scientifically [M]. Japan: Japanese Economic News Press, 1989: 154. (In Japanese)

[5] Minoru Kawada. The Description of Japan by KunioYanagita- The Conception of Folklore and [M]. Translated by LianyouGuo. Beijing: Foreign Language Teaching and Researching Press, 2008: 13. (In Chinese) 